Saint Louis University School of Law Scholarship Commons

All Faculty Scholarship

2018

\title{
Local Human Rights Lawyering
}

Lauren Bartlett

Saint Louis University School of Law, lauren.bartlett@slu.edu

Follow this and additional works at: https://scholarship.law.slu.edu/faculty

Part of the Comparative and Foreign Law Commons, Courts Commons, $\underline{\text { Human Rights Law }}$ Commons, and the International Law Commons

\section{Recommended Citation}

Bartlett, Lauren, Local Human Rights Lawyering (December 11, 2018). Local Human Rights Lawyering, 62 ST. LOUIS U. L.J. 887 (2018).

This Article is brought to you for free and open access by Scholarship Commons. It has been accepted for inclusion in All Faculty Scholarship by an authorized administrator of Scholarship Commons. For more information, please contact erika.cohn@slu.edu, ingah.daviscrawford@slu.edu. 


\section{LOCAL HUMAN RIGHTS LAWYERING}

\section{LAUREN E. BARTLETT ${ }^{*}$}

\section{(Forthcoming as Local Human Rights Lawyering, 62 ST. LOUIS U. L.J. (Winter 2018))}

\section{INTRODUCTION}

International human rights offer a powerful set of norms that have helped domestic advocates to successfully secure additional civil, political, economic and social rights for those living in poverty in the U.S. ${ }^{1}$ Legal aid attorneys, public defenders, and other public interest advocates have recognized human rights as an additional advocacy tool and are increasingly using human rights arguments ${ }^{2}$ in U.S. courts. ${ }^{3}$ This article examines three cases in which legal

\footnotetext{
* Director of Legal Clinics and Assistant Professor of Law at Ohio Northern University Claude W. Pettit College of Law. Thank you to Sabrina Balgamwalla, Elizabeth Clarke, Tim Curry, Martha Davis, Margaret Drew, and Hadar Harris, for ideas and support. Thank you to Christopher Calpin, Shelby Core, and Dustin Green, for research assistance. A special thank you to the Saint Louis University Law Journal for the invitation to present at the 2017 Childress Symposium.

${ }^{1}$ See, e.g., Scott L. Cummings, The Internationalization of Public Interest Law, 57 DuKE L.J. 891, 895 (2008); Martha F. Davis, Human Rights in the Trenches: Using International Human Rights Law in "Everyday" Legal Aid Cases, 41 Clearinghouse Rev. J. Poverty L. \& Pol’y 414, 414-15 (2007) [hereinafter Human Rights in the Trenches]; Martha F. Davis, The Pendulum Swings Back: Poverty Law in the New and Old Curriculum, 34 FORDHAM URB. L.J. 1391, 1395 (2007).

${ }^{2}$ For the purposes of this article, the terms "human rights" and "human rights argument" are used loosely to include any reference or citation to: human rights law; human rights language or terminology; comparative law and international law; international or transnational practices or standards; and practices or standards in countries other than the United States. U.N. Off. of the High Comm'r for Hum. Rts., What Are Human Rights?, http://www.ohchr.org/EN/Issues/Pages/WhatareHumanRights.aspx [https://perma.cc/92LJ-KJAS].

${ }^{3}$ See e.g., Hope Lewis, "New” Human Rights: U.S. Ambivalence Toward the International Economic and Social Rights Framework, in BRINGING Human Rights Home 134 (Cynthia Soohoo, Catherine Albisa, \& Martha F. Davis eds., 2008); Ford Found., CLOSE TO HOME: CASE STUdies OF HuMAN RightS WORK IN THE UNITED STATES 98 (2004) (discussing case studies of human rights work in the U.S.); OPPORTUNITY AGENDA \& THE PROGRAM ON Human RightS AND tHE Global ECONOMY, HuMAN RightS IN STATE COURTS 6-12 (2016) (detailing U.S. court decisions that have considered and interpreted human rights law); AM. U. WASH. COLLEGE OF LAW CENTER FOR

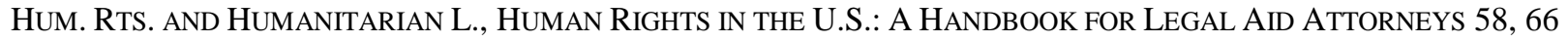
(2014) (providing examples of briefs and descriptions of cases where legal aid attorneys used human rights arguments) [hereinafter HANDBOOK].
} 
aid attorneys and public defenders successfully used human rights arguments in U.S. courts, and discusses emerging best practices for using human rights in litigation in the U.S. ${ }^{4}$

A strong foundation has been laid for legal aid attorneys and public defenders to use human rights arguments in U.S. courts. Many scholars and practitioners have offered persuasive arguments as to why human rights arguments should be made in U.S. courts. ${ }^{5}$ Some of these arguments have even focused on legal aid attorneys and public defenders that set foot in the courtroom almost every day. ${ }^{6}$ In addition, specific types of cases that might be appropriate for human rights have been identified, as well as what human rights strategies might be considered. ${ }^{7}$ Others have reported on successful human rights advocacy in U.S. courts and before U.S. policymakers, including notable victories using human rights arguments. ${ }^{8}$

\footnotetext{
${ }^{4}$ This article discusses three particular cases in which public defenders and legal aid attorneys used human rights arguments: People v. House, 72 N.E.3d 357, 382 (Ill. App. Ct. 2015); Rivero v. Montgomery Cty., Md., 259 F.Supp.3d 334, 349-350 (D. Md. 2017);; Belanger v. Mulholland, 30 A.3d 836, 838 (Me. 2011).

${ }^{5}$ See, e.g., Deena Hurwitz, Lawyering for Justice and the Inevitability of International Human Rights Clinics, 28 YALE J. INT'L L. 505, 524 (2003); Judith Resnik, Law's Migration: American Exceptionalism, Silent Dialogues, and Federalism's Multiple Ports of Entry, 115 YALE L.J. 1564, 1627-29 (2006); Cynthia Soohoo \& Suzanne Stolz, Bringing Theories of Human Rights Change Home, 77 FORDHAM L. REV. 459, 469 (2008). See also STEPHEN

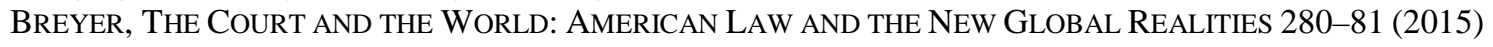
(discussing the U.S. Supreme Court increasing trend towards consideration of foreign activities and international law).

${ }^{6}$ See Human Rights in the Trenches, supra note 1, at 415 (“[I]nternational human rights are relevant to even the most mundane and local case.”). Public Defenders and legal aid attorneys are in the courtroom on an almost daily basis and handle many, if not too many, cases at a time. See, e.g., Vida B. Johnson, A Plea for Funds: Using Padilla, Lafler, and Frye to Increase Public Defender Resources, 51 AM. CRIM. L. REV. 403, 404 (2014); LEGAL SERVS. CORP., DOCUMENTING THE JUSTICE GAP IN AMERICA: THE CURRENT UNMET CIVIL LEGAL NEEDS OF LOWINCOME AMERICANS 2-3 (2009) (discussing unmet needs of potential legal aid clients, but also discussing the great numbers of clients served). The possibility of public defenders and legal aid attorneys using human rights in their cases means these arguments could be presented on a regular basis, many times over, before U.S. courts. Public Defenders and legal aid attorneys are also in the unique position of handling so many cases, and declining even more, that they may be able to pick and choose which cases would be best for human rights arguments.

${ }^{7}$ See also HANDBOOK, supra note 3; NAT'L JuV. DEFENDER CTR., INTERNATIONAL HUMAN RIGHTS: LAW \& RESOURCES FOR DEFENDERS \& ADVOCATES 3-6 (2012); COluM. L. SCH. Hum. RightS InST., HuMAN RightS, SoCIAL JUSTICE, AND STATE LAW: A MANUAL FOR CREATIVE LAWYERING, 30-31 (2008) [hereinafter MANUAL FOR CREATIVE LAwYERING]. The Bringing Human Rights Home Lawyers' Network (“BHRH Lawyers' Network”) at Columbia Law School's Human Rights Institute, houses a U.S. Human Rights Online Library, which serves as an online clearinghouse for domestic human rights resources, including sample briefs, pleadings, and other materials relevant to BHRH Lawyers' Network members. See U.S. Human Rights Online, Colum. L. ScH. Hum. RigHTS InST, http://www.law.columbia.edu/human-rights-institute/us-human-rights-online [https://perma.cc/2PTG-K5AX].

${ }^{8}$ See FORD Found., supra note 3, at 11; SoOHOO, supra note 3, at 130-31.
} 
Both attorneys and decision-makers are increasingly more familiar with human rights norms than ever before. ${ }^{9}$ In addition, more and more cities and counties in the U.S. are passing resolutions and ordinances that endorse or incorporate human rights law. ${ }^{10}$ These local human rights resolutions and ordinances can be cited in briefs and oral arguments. ${ }^{11}$ Moreover, choice of legal precedent to point to in U.S. courts increases with each new decision citing to human rights law. ${ }^{12}$

Efforts to support and train U.S. lawyers to use human rights in U.S. courts are numerous. Groups such as the U.S. Human Rights Network, ${ }^{13}$ the Bringing Human Rights Home Lawyers’ Network, ${ }^{14}$ Human Rights Institute at Columbia Law School, ${ }^{15}$ Program on Human Rights and Global Economy at Northeastern University School of Law, ${ }^{16}$ Local Human Rights Lawyering

\footnotetext{
${ }^{9}$ Law schools are increasingly offering international law courses and international human rights law clinics are flourishing across the U.S. See, e.g., Farida Ali, Globalizing the U.S. Law School Curriculum: How Should Legal Educators Respond?, 41 INT'L J. LEGAL INFO. 249, 266-69 (2013); Hurwitz, supra note 4, at 507. Martha F. Davis, Johanna Kalb, and Risa E. Kaufman have published a casebook on human rights in the U.S. for law students, as well. Martha F. DAVIS ET AL., Human Rights AdVOCACY IN THE United STATES (2014) [hereinafter HuMAN RighTS ADVOCACY CASEBOOK]. The Aspen Institute has held seminars for U.S. judges on international law. Justice and Society Program ASPEN INST., https://www.aspeninstitute.org/programs/justice-and-society-program/ [https://perma.cc/3KXG-NF6V].

${ }^{10}$ See Colum. L. Sch. Hum. RTS. Inst., Bringing Human Rights Home: How State AND LOCAl Governments Can Use Human Rights to Advance Local Policy 5, 13-16 (2012); Joann Kamuf Ward \& Sarah Paoletti, Human Rights Developments at the State and Local Level in the United States: A Bird's-Eye View, 87 PA. BAR Ass'N. Q. 63, 63-66 (2016). See also List of Freedom from Domestic Violence Local Resolutions, CORNELL L. SCH. GLOBAL GENDER JUSTICE CLINIC, http://www.lawschool.cornell.edu/womenandjustice/DV-Resolutions.cfm [https://perma.cc/DR9U-K8LV].

${ }^{11}$ See MANUAL FOR CREATIVE LAWYERING, supra note 6.

${ }^{12}$ See OPPORTUNiTy AgENDA, supra note 3.

${ }^{13}$ The U.S. Human Rights Network puts on annual conferences, and organizes webinars, trainings, and other materials for U.S. attorneys and non-attorney activists. U.S. HUM. RTS. NETWORK, https://www.ushrnetwork.org/ [https://perma.cc/VPS5-YFBB].

${ }^{14}$ The BHRH Lawyers' Network has played an important role in providing trainings and other resources for U.S. attorneys using and looking to use human rights in their work. BHRH LAWYERS' NETWORK, http://www.law.columbia.edu/human-rights-institute/bhrh-lawyers-network [https://perma.cc/MG5Y-FRCD].

${ }^{15}$ The Human Rights Institute at Columbia Law School organizes an annual day-long CLE on human rights in the U.S., and has also published reports and guides for U.S. attorneys. Publications, ColUM. L. SCH. HuM. RTS. INST., http://www.law.columbia.edu/human-rights-institute/initiatives/about/publications [https://perma.cc/2QKP-VEHQ].

${ }^{16}$ The Program on Human Rights and the Global Economy at Northeastern Law ("PHRGE”) organizes annual human rights conferences, and includes legal aid attorneys at those conferences. Fall Human Rights Institutes, Ne. U. Sch. of L Program on Hum. Rts. and the Global Economy, http://www.northeastern.edu/law/academics/institutes/phrge/events/institutes/index.html [https://perma.cc/RZF7B7S8].
} 
Project at American University Washington College of Law, ${ }^{17}$ and the Pillar Project at Human Rights First, ${ }^{18}$ have helped to promote human rights advocacy, as well as to support and train U.S. lawyers to use human rights law in U.S. courts. These groups have identified specific human rights law relevant to legal aid and public defender cases, and explained the applicability of human rights in the context of domestic advocacy, as well as the challenges to citing to human rights as binding law. ${ }^{19}$

Given the foundation that has been laid, as well as the fact that legal aid attorneys and public defenders have been using human rights in U.S. courts for some time, it is time to examine cases in detail to identify emerging best practices and lessons learned. Focusing on three cases in which international human rights arguments were made by legal aid attorneys and public defenders, this article provides practical how-to advice to further encourage legal aid attorneys and public defenders to use human rights in U.S. courts.

\footnotetext{
${ }^{17}$ The Local Human Rights Lawyering project (“LHRL project”) at the Center for Human Rights \& Humanitarian Law at American University Washington College of Law was a 4-year long project dedicated to providing support and resources to legal aid attorneys and public defenders to use human rights in their everyday practice. See Lauren E. Bartlett, A Human Rights Code of Conduct: Ambitious Moral Aspiration for a Public Interest Law Office or Law Clinic, 91 St. John's L. Rev. (Forthcoming 2017). The LHRL project published and widely distributed the Human Rights in the U.S.: A Handbook for Legal Aid Attorneys, provided webinars and in-person trainings on human rights issues for hundreds of attorneys across the U.S., and also provided financial support for Maryland Legal Aid and Texas Rio Grande Legal Aid to hire two attorneys as human rights coordinators (2012-2014). The author of this article is the former director of the LHRL project. See Local Human Rights Lawyering Project, Am. U. Wash. College of Law Center for Hum. Rts. and Humanitarian L., https://www.wcl.american.edu/impact/initiatives-programs/center/programs/past-initiatives/lawyering/ [https://perma.cc/WU6T-YLF7].

${ }^{18}$ Human Rights First's Pillar Project was also dedicated to advancing human rights law in U.S. Courts, mainly through the organizing of amicus briefs. Hum. Rights First, The Pillar Project: Advancing Human Rights in U.S. Courts 1-3 (2012), https://www.humanrightsfirst.org/wpcontent/uploads/pdf/pillar_project_announcement_2012.pdf.

${ }^{19}$ See, e.g., Handbook, supra note 3, at 18-19 (providing a brief explanation of reservations, understandings, and declarations assigned by the U.S. government when ratifying human rights treaties); Human Rights Advocacy Casebook, supra note 8, at 153-75, 232-65 (discussing the difficulties of enforcing human rights treaties and international customary law in U.S. courts); Manual for Creative Lawyering, supra note 6, at 7-8 (discussing the relationship between state law and transnational law).
} 


\section{CASE EXAMPLES From U.S. COURTS: Human RightS ARgumentS MADE BY Legal Aid Attorneys And Public Defenders}

This section examines three cases in which human rights arguments were made by either legal aid attorneys or public defenders in U.S. courts. While there are additional cases that could be discussed, these cases were selected to illustrate emerging best practices.

\section{a. Case Example 1: People v. Antonio House ${ }^{20}$}

Recent developments in state and federal law, including limits on sentencing juveniles to life without parole and ending the juvenile death penalty, make cases involving young adults in the criminal justice system ripe for human rights arguments. ${ }^{21}$ The People v. House case offers a great example of public defenders using a human rights argument successfully in a state court.

Defendant Antonio House was 19 years old in 1993 when he was alleged to be part of a group that kidnapped two members of a rival gang, took them to a vacant lot, and shot them both. ${ }^{22}$ Mr. House was not present at the scene of the murder, but was alleged to have acted as a lookout nearby. ${ }^{23}$ There was no evidence that Mr. House helped plan the crime. ${ }^{24}$ Instead, he was alleged to have taken orders from higher-ranking gang members. ${ }^{25}$ Despite a vigorous defense, the jury found Mr. House guilty of two counts each of first degree murder and aggravated kidnapping. ${ }^{26}$ The Court subsequently sentenced Mr. House to two consecutive life

\footnotetext{
${ }^{20}$ People v. House, 72 N.E.3d 357, 357-38 (Ill. App. Ct. 2015).

${ }^{21}$ See NAT'L Juv. DefEndER CTR., supra note 7. For example, while the U.S. Supreme Court did not rely on human rights law to invalidate the juvenile death penalty, it did recognize international law as a "respected and significant" influence. Roper v. Simmons, 543 U.S 551, 578 (2005). In addition, in Graham v. Florida, the U.S. Supreme Court discussed international law and the U.N. Convention on the Rights of the Child, in its decision to overturn juvenile life without parole for non-homicide crimes. 560 U.S. 48, 80-82 (2010).

${ }^{22}$ House, 72 N.E.3d at 368.

${ }^{23} \mathrm{Id}$. at 384 .

${ }^{24} \mathrm{Id}$.

${ }^{25} \mathrm{Id}$.

${ }^{26} \mathrm{Id}$. at 364 .
} 
sentences for the murder convictions and two consecutive 60-year sentences for the aggravated kidnapping convictions. ${ }^{27}$

In 2014, an appeal was brought by appellate defenders Michael Pelletier, Jessica Fortier, and Alan Goldberg. ${ }^{28}$ Among other arguments the appellate defenders offered, was that the mandatory natural life sentence violated the Eighth Amendment of the United States Constitution and the proportionate penalties clause of the Illinois Constitution. ${ }^{29}$ The defenders argued that the life sentence is mandated for all offenders convicted of murder of more than one individual without consideration of age or level of culpability. ${ }^{30}$ They stated that the life sentence was invalid as applied to Mr. House because of his young age and minimal involvement in the commission of the crimes. ${ }^{31}$ The defenders cited to recent U.S. Supreme Court decisions Roper v. Simmons, Graham v. Florida, and Miller v. Alabama, all of which included international comparative discussions of criminal justice practices for child defendants. ${ }^{32}$ The defenders also cited to articles that included discussion of international sentencing practices for juveniles and young adults. ${ }^{33}$

The Illinois appellate court took these human rights arguments and ran with them. In its decision, the Court discussed the U.S. Supreme court decisions in depth. ${ }^{34}$ The Court noted that Illinois had raised the age from 17 to 18 in 2014, and recognized that several other U.S. states had recently raised the age for mandatory sentencing as well. ${ }^{35}$ And, notably, the Court spent a

${ }^{27}$ House, 72 N.E.3d at 369.

${ }^{28}$ Id. at 363.

${ }^{29}$ Brief for Petitioner at 58-59, People v. House, 72 N.E.3d 357 (Ill. App. Ct. 2015) (No. 1-11-0580).

${ }^{30}$ Id.

${ }^{31}$ Id. at 64.

${ }^{32}$ Id. For discussion of international practices for children as criminal defendants, see Miller v. Alabama, 567 U.S. 460, 471-72 (2012); Graham v. Florida, 560 U.S. 48, 80-82 (2010); Roper v. Simmons, 543 U.S 551, 578 (2005).

${ }^{33}$ Brief for Petitioner, People v. House, 72 N.E.3d 357, at 61-62.

${ }^{34}$ House, 72 N.E.3d at 382-86.

${ }^{35}$ Id. at 387-88. 
whole paragraph of its decision discussing the juvenile sentencing practices of several European countries, including Germany, Sweden and the Netherlands. ${ }^{36}$

Accordingly, the Court held that "we find that defendant's mandatory sentence of natural life shocks the moral sense of the community...We vacate defendant's sentence of natural life and remand for a new sentencing hearing.”37

The appellate defenders in this case made good use of human rights arguments. The defenders cited to articles and cases that emphasized international sentencing practices as ideal, and compared U.S. practices to the international practices. This is an example of a "human rights argument," ${ }^{38}$ which includes referencing another country's practice and legal system to inform and mold U.S. law and practices.

The use of human rights arguments in the House case resonated with the Illinois appellate court, just as these same sorts of arguments worked well with the U.S. Supreme Court in Roper v. Simmons and Graham v. Florida. ${ }^{39}$ The comparison of U.S. mandatory sentencing practices with the practices of more "advanced" countries, like Sweden and the Netherlands, ${ }^{40}$ made the U.S. mandatory sentencing practices look "backward" or at least out of line with the international practices.

\footnotetext{
${ }^{36}$ Id. at 387.

${ }^{37}$ Id.at 389.

${ }^{38}$ See What Are Human Rights?, supra note 2.

${ }^{39}$ See Roper, 543 U.S. at 578; Graham, 560 U.S. at 81-82.

${ }^{40}$ There are many examples of U.S. politicians and social scientists pointing to Sweden, the Netherlands, and other European countries as having better practices or statistics regarding education, health, infrastructure, crime, etc. than the U.S. See, e.g., GEORGE LAKEY, Viking ECONOMICS: How The SCANDinaVians Got It Right - AND How WE CAN, Too (2017) (showing Nordic economies boast the world's happiest, most productive workers); ERIC C. SCHNEIDER ET AL., MiRROR, MiRROR 2017: INTERNATIONAL COMPARISON REFLECTS FlAWS AND OPPORTUNITIES FOR BetTeR U.S. HealthCARE 5-7 (2017); Erin Grinshteyn \& David Hemenway, Violent Death Rates: The US Compared with Other High-income OECD Countries, 2010, 129 AM. J. MED. 266, 270-71 (2016); Frida Ghitis, Holland Has Solved this Problem; Why Can't the US?, CNN, Aug. 29, 2017, https://www.cnn.com/2017/08/29/opinions/dutch-america-storms-opinion-ghitis/index.html [https://perma.cc/XWH7-H9GP].
} 
This type of comparative international argument, where U.S. practices are compared with international practices seems to work well with decision-makers in the U.S. Maybe this type of argument works because it begins to reveal the fallacy of the deeply ingrained belief in American exceptionalism. ${ }^{41}$ Arguments that compare and contrast U.S. and international practices, and lump the U.S. together with countries whose practices the U.S. general public does not generally like or think of as advanced, such as North Korea, Sudan, Iran, also resonate strongly with judges. $^{42}$ It is particularly striking for a country that thinks of itself as exceptional to be portrayed as unexceptional.

The comparative international argument may also work because it has been heard by decision makers before and so much in our modern society is transnational. What we do for work, where we travel, what we buy, what we eat, all involves transnational practices. The comparison of hot house tomatoes from the U.S. and Mexico ${ }^{43}$ is the norm, something we do in grocery stores every day, and it should not be surprising these international comparative arguments resonate with judges.

\section{b. Case Example 2: Rivero v. Montgomery County, Maryland ${ }^{44}$}

Migrant farmworker attorneys across the U.S. struggle to get access to their clients, who often live and work on farm property. ${ }^{45}$ Attorneys and outreach workers across the U.S. have faced trespassing charges when trying to get access to their clients and conduct outreach on farm

\footnotetext{
${ }^{41}$ See, e.g., Godfrey Hodgson, The Myth OF AMERICAN EXCEPTIONAlism 128-129 (2009); Harold Hongju Koh, On American Exceptionalism, 55 STAN. L. REV. 1479, 1484-85 (2003); Resnik, supra note 4, at 1575.

${ }^{42}$ See, e.g., Roper v. Simmons, 543 U.S. 551, 577 (2005).

${ }^{43}$ See Dan Charles, The Search for Tastier Supermarket Tomatoes: A Tale in Three Acts, NAT’L PuB. RADIO, InC. (Jun. 3, 2016, 4:58 AM), https://www.npr.org/sections/thesalt/2016/06/03/479632322/the-search-for-tastiersupermarket-tomatoes-a-tale-in-three-acts [https://perma.cc/BV96-DCQH].

${ }^{44}$ Rivero v. Montgomery Cty., Md., 259 F.Supp.3d 334, 349-350 (D. Md. 2017).

${ }^{45}$ Access to clients and potential clients who live and work on farm property has been denied not just to labor organizers and attorneys, but also to healthcare workers, religious outreach workers, social workers and more. See Reena K. Shah \& Lauren E. Bartlett, Human Rights in the United States: Legal Aid Alleges that Denying Access to Migrant Labor Camps is a Violation of the Human Right to Access Justice, 20 HUM. RTS. BR. 15, 15-21 (2012).
} 
property. ${ }^{46}$ This case, Rivero v. Montgomery County, involves trespassing charges issued against a Maryland Legal Aid Bureau, Inc. (“Maryland Legal Aid”), ${ }^{47}$ farmworker outreach worker, and legal intern who were attempting to visit potential clients on farm property. ${ }^{48}$ Maryland Legal Aid, along with others, brought this case and successfully used human rights arguments in their complaint.

In Rivero, the owners of a farm called the police after finding Ms. Rivero, a farmworker outreach worker for Maryland Legal Aid, and her colleague, a legal intern, on their property. ${ }^{49}$ The Montgomery County police officer who responded issued trespassing tickets against Ms. Rivero and the legal intern. ${ }^{50}$

Maryland Legal Aid's complaint was filed in federal court against both the farm and Montgomery County, and alleged violations of the First and Fourteenth Amendments of the U.S. Constitution, as well as the Maryland Declaratory Judgment Act. ${ }^{51}$ Maryland Legal Aid stated in its complaint that:[C]oalitions of legal aid groups, advocacy groups, health care organizations, and legal clinics have petitioned Human Rights officials for both the United Nations and the Organization of American States for investigation into the widespread denial of access for outreach workers to migrant worker camps in the United States. ${ }^{52}$

Two human rights reports were also cited by Maryland Legal Aid. ${ }^{53}$ The first report was

submitted to the U.N. Special Rapporteur on Extreme Poverty and Human Rights and the second report was submitted to the Inter-American Commission on Human Rights. ${ }^{54}$ These reports

\footnotetext{
${ }^{46} I d$.

${ }^{47}$ MARYLAND LEGAL AID, www.mdlab.org [https://perma.cc/DLL6-VSAP].

${ }^{48}$ Complaint $\llbracket 2-3$, Rivero et al v. Montgomery Cty., Md. et al, 259 F.Supp.3d 334 (D. Md. 2017) (8:16-cv-01186PWG).

${ }^{49}$ Id. $\Upsilon 3$.

${ }^{50} \mathrm{Id}$.

${ }^{51}$ Id. $\uparrow 51-57,958-64$.

${ }^{52} I d$. $\$ 32$.

${ }^{53}$ Complaint 933 , Rivero et al v. Montgomery Cty., Md. et al, 259 F.Supp.3d 334 (D. Md. 2017) (8:16-cv-01186PWG).

${ }^{54}$ See Report to U.N. Special Rapporteur on Extreme Poverty and Human Rights (Dec. 13, 2012), ttp://www.coloradofarmworkers.org/wp-content/uploads/2017/11/Migrant-Farmworker-Camp-Access-HumanRights-Complaint-Dec-13-2012.pdf; Report to Exec. Sec'y of the Inter-American Comm'n on Human Rights (Jan. 20, 2014), http://www.wjcny.org/wpcontent/ uploads/2014/01/Denial-of-Migrant-Labor-Camp-Access-in-the-US-20Jan2014.pdf. For more on special rapporteurs and international mechanisms, see HANDBOOK, supra note 3, at 27-28.
} 
documented human rights violations related to the denial of migrant farmworker access across the U.S. ${ }^{55}$

In addition to the human rights reports, the complaint also cited to a letter written by the U.N. Special Rapporteurs on Extreme Poverty and Human Rights, on the Situation of Human Rights Defenders, and on the Human Rights of Migrants. ${ }^{56}$ This letter was sent as an official communication to the U.S. government expressing the Special Rapporteurs' concerns after the receipt of the above-mentioned reports, and requested a response from the U.S. government. ${ }^{57}$ The complaint noted that the U.S. government did not deny the coalitions' allegations in its official response to the special rapporteurs. ${ }^{58}$

In response to Maryland Legal Aid's complaint, the farm and county defendants filed a motion to dismiss, arguing that that Ms. Rivero lacked standing to seek declaratory relief because she lacked a "personal stake” in the outcome of the case and had only plead an "abstract injury." ${ }^{59}$ In doing so, they cited to Los Angeles v. Lyons, a U.S. Supreme Court case. ${ }^{60}$ In Lyons, an individual who had been subjected to a chokehold by the police was held to lack standing to pursue injunctive relief against police because he could not establish more than a speculative risk of experiencing another chokehold. ${ }^{61}$

The federal court in Maryland denied the defendants' motion to dismiss, holding that Maryland Legal Aid had showed that this camp access problem was likely to occur again, had been happening across the county, and that Ms. Rivero had standing. ${ }^{62}$ The Court cited to the U.N. Special Rapporteur on Extreme Poverty report—-the report that Maryland Legal Aid had

\footnotetext{
${ }^{55}$ See Shah, supra note 45 , at $15-16$.

${ }^{56}$ Complaint, Rivero, 259 F.Supp.3d 334, $\mid 33$.

${ }^{57} \mathrm{Id}$.

${ }^{58} I d$.

${ }^{59}$ Rivero v. Montgomery County, Maryland, 259 F.Supp.3d 334, 341-42 (D. Md. 2017).

${ }^{60}$ Los Angeles v. Lyons, 461 U.S. 95, 101-02 (1983).

${ }^{61} \mathrm{Id}$.

${ }^{62}$ Rivero, 259 F.Supp.3d at 340.
} 
cited in its complaint—as evidence of the practice of denying migrant farmworker access, stating that "the likelihood of future controversies of a similar ilk is far from speculative or abstract.”63 This case did not go any further, as the parties entered into a settlement in October $2017 .{ }^{64}$

The Rivero case offers a good example of how human rights documentation can be used as evidence in U.S. litigation. Human rights reports and communications from special rapporteurs cannot be cited to as binding law, ${ }^{65}$ but can be cited to as evidence of violations of the law. ${ }^{66}$

In Rivero, Maryland Legal Aid cited to two human rights reports and a statement by special rapporteurs to the U.S. government as evidence. ${ }^{67}$ The human rights reports in Rivero helped to prove facts that were required for standing purposes to survive a motion to dismiss. ${ }^{68}$ The human rights reports used in Rivero also helped to get the attention of the decision maker. The state or federal court judge does not normally see international documents cited to in a brief. This can help a case stand out.

This use of human rights reports in litigation in a U.S. court by Maryland Legal Aid demonstrates how advocacy before international forums and international mechanisms can help prove facts in state and local courts, and especially when seeking to survive a motion to dismiss.

\section{c. Case Three: Belanger v. Mulholland ${ }^{69}$}

In the Belanger case, the Supreme Court of Maine held that the implied warranty of habitability includes running water and a functioning toilet. ${ }^{70}$ The legal aid attorney who brought

\footnotetext{
${ }^{63} \mathrm{Id}$. at 342.

${ }^{64}$ Letter to Judge Grimm re: Settlement Status, Rivero v. Montgomery County, Maryland, 259 F.Supp.3d (D. Md. Oct. 2, 2017) (8:16-cV-01186-PWG).

65 See, e.g., HANDBOOK, supra note 4, at 18-19.

${ }^{66} \mathrm{Id}$.

${ }^{67}$ Complaint \32-33, Rivero et al v. Montgomery Cty., Md. et al, 259 F.Supp.3d 334 (D. Md. 2017) (8:16-cv01186-PWG).

${ }^{68}$ Rivero et al v. Montgomery Cty., Md. et al, 259 F.Supp.3d 334, 340 (D. Md. 2017).

${ }^{69}$ Belanger v. Mulholland, 30 A.3d 836 (Me. 2011).
} 
and argued this case, Judy Plano of Pine Tree Legal Assistance (“Attorney Plano”), ${ }^{71}$ offered a terrific example of structure for a human rights argument.

The facts of this case stand out as particularly egregious. The Plaintiffs and Appellants, Leo and Germaine Belanger (“the Belangers”), were tenants in a mobile home park in Augusta, Maine. ${ }^{72}$ The conditions of the mobile home, "while livable at the time the Belangers moved into it, significantly deteriorated over the more than twenty years that they lived there.”73

In December 2008, the water pipes froze and burst in the mobile home, and the Belangers had no running water. ${ }^{74}$ The Belangers reported the broken pipes to their landlord, the owner of the mobile home park, John Mulholland, and he asserted he had no obligation to make repairs. ${ }^{75}$ The landlord did allow the Belangers a rent abatement to allow them to use those funds to pay for repairs. ${ }^{76}$ However, the repairs were unsuccessful. ${ }^{77}$ The Belangers, elderly and disabled, ${ }^{78}$ “made do by buying bottled water and hauling water from a neighbor’s home.”,79

Then, in March 2009, the toilet would not flush. ${ }^{80}$ The landlord, again, refused to make repairs. ${ }^{81}$ The Belangers then resorted to hauling their human waste in a bucket outside to the septic tank. ${ }^{82}$ This continued for five months. ${ }^{83}$

${ }^{70}$ Id. at 838 .

${ }^{71}$ Id. at 837. Pine Tree Legal Assistance provides free civil legal assistance, including in cases to enforce basic human rights such as access to housing, food, income, safety, education, and healthcare. Our Mission and Services, PINE TREE LEGAL AssistANCE, https://ptla.org [https://perma.cc/UQR8-BC5P].

${ }^{72}$ Brief for Appellants at 1, Belanger v. Mulholland, 30 A.3d 836 (Me. 2011) (No. KEN-11-132).

${ }^{73}$ Id.

${ }^{74}$ Belanger, 30 A.3d at 837.

${ }^{75} \mathrm{Id}$.

${ }^{76} \mathrm{Id}$.

${ }^{77} \mathrm{Id}$.

${ }^{78}$ Brief for Appellants, Belanger, 30 A.3d 836, at 3.

${ }^{79}$ Belanger, 30 A.3d at 837.

${ }^{80} \mathrm{Id}$.

${ }^{81} I d$.

${ }^{82}$ Brief for Appellants, Belanger, 30 A.3d 836, at 3.

${ }^{83} \mathrm{Id}$. at 5. 
In May 2009, with help from Attorney Plano, the Belangers sued their landlord for breach of the implied warranty of habitability. ${ }^{84}$ The trial court found for the Belangers, but found the combination of both the lack of water and sanitation were "together sufficient" to constitute a breach of the implied warranty of habitability, and awarded the Belangers $\$ 2,500$ in damages for the five months of rent they were without a functioning toilet. ${ }^{85}$ The Belangers moved to amend to include damages for the four months that they were without water. ${ }^{86}$ The court denied that motion. $^{87}$

The Belangers appealed, and in the brief on appeal Attorney Plano argued that the lack of running water was in and of itself a violation of the implied warranty of habitability. ${ }^{88}$ First, Attorney Plano examined local law in the City of Augusta, Maine, and argued that the lack of running water should be interpreted as a per se violation of the warranty of habitability. ${ }^{89}$

Next, Attorney Plano compared warranty of habitability laws across the U.S. and pointed out that in "thirty-three (33) states, laws specifically mention the landlord's duty to provide running water. The failure to do so is a violation of the warranty of habitability laws and makes a dwelling unfit for human habitation." ${ }^{90}$ She argued that the warranty of habitability standard in Maine should be consistent with national standards regarding the rights to adequate housing, water, and sanitation. ${ }^{91}$

Attorney Plano then argued that the domestic warranty of habitability standard should be interpreted consistently with international human rights law standards to reflect the rights to

\footnotetext{
${ }^{84}$ Belanger, 30 A.3d at 838 .

${ }^{85} \mathrm{Id}$.

${ }^{86} \mathrm{Id}$.

${ }^{87} \mathrm{Id}$.

${ }^{88}$ Brief for Appellants at 8-19, Belanger v. Mulholland, 30 A.3d 836 (Me. 2011) (No. KEN-11-132).

${ }^{89}$ Id. at 13.

${ }^{90} \mathrm{Id}$. at 15.

${ }^{91}$ Id.
} 
adequate housing, water, and sanitation. ${ }^{92}$ Her human rights argument began with an argument as to why international human rights law was being examined in this housing case at all:

[w] here domestic Constitutional or statutory law is vague, courts have looked to treaties and international law for interpretive guidance. 'The opinion of the world community, while not controlling our outcome, does provide respected and significant confirmation for our own conclusions. ${ }^{93}$

She cited to U.S. cases that support and restate this proposition, ${ }^{94}$ including the Roper $v$. Simmons case, ${ }^{95}$ from which the quote is taken.

Attorney Plano then went on to argue that "[u]nder international human rights norms, the mere fact that the Belangers had a roof over their heads fails to satisfy applicable legal standards. ${ }^{, 96}$ She cited to the International Covenant on Economic Social and Cultural Rights, ${ }^{97}$ the U.N. Committee on Economic, Social and Cultural Rights, ${ }^{98}$ the U.N. Special Rapporteur on the relationship between the enjoyment of economic, social and cultural rights and the promotion of the realization of the right to drinking water supply and sanitation, ${ }^{99}$ the U.N. Secretary General, ${ }^{100}$ and the U.N. High Commissioner for Human Rights, ${ }^{101}$ all interpreting the right to adequate housing.

\footnotetext{
${ }^{92}$ Id. at $16-17$.

${ }^{93}$ Brief for Appellants at 16, Belanger v. Mulholland, 30 A.3d 836 (Me. 2011) (No. KEN-11-132).

${ }^{94}$ Id. Specifically, Plano cited to a former Maine Supreme Court case where the court had looked to European common law to support finding parents had a fundamental right to control the upbringing of their children. State v. Wilder, 748 A.2d 444, 449 n.6 (Me. 2000).

${ }^{95}$ Roper v. Simmons, 543 U.S. 551, 578 (2005).

${ }^{96}$ Brief for Appellants, Belanger v. Mulholland, 30 A.3d 836, at 16.

${ }^{97}$ International Covenant on Economic, Social, and Cultural Rights art. 11, ๆ1, Dec. 16, 1966, 993 U.N.T.S. 3.

${ }^{98}$ U.N. Office of the High Comm'r for Hum. Rts, Committee on Economic, Social and Cultural Rights General Comment No. 4: The Right to Adequate Housing (Art. 11(1) of the Covenant), ๆ1, U.N. Doc. E/1992/23 (Dec. 13, 1991).

${ }^{99}$ Special Rapporteur El Hadji Guissé to the U.N. Comm'n on Human Rts., Economic, Social, and Cultural Rights: Relationship between the enjoyment of economic, social and cultural rights and the promotion of the realization of the right to drinking water supply and sanitation, 9 ฯ1-2, U.N. Doc. E/CN.4/Sub.2/2002/10 (June 25, 2002).

${ }^{100}$ U.N. Secretary-General, Compilation of Guidelines on the Form and Content of Reports To Be Submitted By States Parties To the International Human Rights Treaties, ๆ 50, U.N. Doc. HRI/GEN/2/Rev.6 (Jun. 3, 2009).

${ }^{101}$ U.N. Office of the High Comm'r for Hum. Rts, The Right to Adequate Housing, Fact Sheet No. 21/Rev. 1, (May 2014), http://www.ohchr.org/Documents/Publications/FS21_rev_1_Housing_en.pdf.
} 
Attorney Plano continued by arguing that "[t]he right to water is an essential cornerstone for realizing the right to an adequate standard of living as well as the right to health." ${ }^{102}$ She also cited to the Universal Declaration of Human Rights, ${ }^{103}$ reminded the Maine Supreme Court that the U.S. helped draft the Universal Declaration, and quoted the Universal Declaration: "Everyone has the right to a standard of living adequate for the health and well-being of himself and of his family." ${ }^{104}$ She ended her well-crafted human rights argument with the following: "[s]uch deplorable conditions, which are not tolerated under international human rights standards, should not be allowed by Maine laws."

The Supreme Court of Maine agreed with the Belangers and held that the lack of running water in the Belangers' trailer was in and of itself a violation of the implied warranty of habitability. ${ }^{106}$ Unlike in the People v. House decision and the Rivero v. Montgomery County, Maryland Memorandum Opinion, discussed above, the Supreme Court of Maine did not reference international human rights law in its decision. ${ }^{107}$ Yet, the outcome of the case was successful for the Belangers, and the human rights arguments offered were persuasive and likely influenced the court's decision.

The human rights argument offered by Attorney Plano in the Belanger case provides a great example for legal aid attorneys looking to use human rights in state court briefs or other legal documents. Attorney Plano began by explaining why human rights law was relevant to the Supreme Court of Maine. ${ }^{108}$ This relevancy argument is very important. The decision-maker should be told why they should pay attention to an international human rights argument in a state

\footnotetext{
102 Brief for Appellants at 18, Belanger v. Mulholland, 30 A.3d 836 (Me. 2011) (No. KEN-11-132).

103 G.A. Res. 217 (III) A, Universal Declaration of Human Rights (Dec. 10, 1948).

${ }^{104}$ Id. at art. 25, ๆ 1; Brief for Appellants at 18, Belanger v. Mulholland, 30 A.3d 836 (Me. 2011) (No. KEN-11132).

${ }^{105}$ Brief for Appellants, Belanger v. Mulholland, 30 A.3d 836, at 18.

${ }^{106}$ Belanger v. Mulholland, 30 A.3d 836, 838 (Me. 2011).

${ }^{107}$ Id. at 836-38.

${ }^{108}$ Brief for Appellants, Belanger v. Mulholland, 30 A.3d 836, at 16.
} 
or local court. The Human Rights in the U.S.: A Handbook for Legal Aid Attorneys lays out five relevancy arguments that can be used for this purpose. ${ }^{109}$ Perhaps if a judge has heard and positively responded to these relevancy arguments before, then and only then should the relevancy portion of the argument be skipped.

Next, a "hook" to human rights law was used by Attorney Plano. Her hook was that the right to adequate housing, much discussed and defined in the human rights arena, is comparable to the warranty of habitability in domestic law. ${ }^{110}$ This "hook" helps to explain why human rights were relevant in this particular landlord tenant case.

The human rights law itself was then introduced and citations to evidence of the international standards for adequate housing were included. ${ }^{111}$ Attorney Plano then briefly analyzed the facts of Belanger using human rights law, and ended with an argument for interpretation of the local warranty of habitability statute in line with international human rights standards. ${ }^{112}$

Here is a roadmap for making a human rights argument, modeled after the well-structured argument that was used by Attorney Plano in Belanger:

1. Make arguments based in local, state and federal law

2. Explain why human rights law is relevant to this court and this decision-maker

3. Introduce your "hook" to human rights law

4. Introduce the human rights law itself

5. Analyze your facts using human rights law

\footnotetext{
${ }^{109}$ See HANDBOOK, supra note 4, at 38-41; MANUAL FOR CREATIVE LAWYERING, supra note 7, at 28-33 (offering examples of relevancy arguments; this is where some of the Handbook ideas were drawn from).

${ }^{110}$ Brief for Appellants at 16, Belanger v. Mulholland, 30 A.3d 836 (Me. 2011) (No. KEN-11-132).

${ }^{111} I d$.

${ }^{112}$ Id. at $16-18$.
} 
6. End by arguing for an expansion or reinterpretation of U.S. law based on the human rights standards.

This roadmap offers an effective structure for including a human rights argument in a state court brief, and can be replicated by other legal aid attorneys and public defenders considering the inclusion of an international human rights argument in a state or local brief.

\section{Practical Advice for Using Human Rights Arguments in U.S. Courts: TAKEAWAYS AND CAUTIONARY NOTES}

The case examples discussed in this article are meant to demonstrate how, practicallyspeaking, human rights documents, reports, and human rights treaties, can be used in domestic litigation. A few of the takeaways that can be drawn from these cases include the following.

First, consider using human rights reports and other human rights documentation as evidence to help you build your case. This is what Maryland Legal Aid did in the Rivero case. ${ }^{113}$

Second, when the facts of a case are so shocking and so outside of international human rights standards or norms, consider using human rights arguments and citing to international human rights documents to get the judge or decision-maker's attention. Using human rights can help emphasize that this is not just another case among thousands. Attorney Plano successfully used human rights in this way to help highlight the egregious facts of the Belanger case. ${ }^{114}$

Third, structure and build your human rights argument carefully. Begin by comparing local law and practices to statewide law and practices, and then look at federal law and nationwide practices. Top off those local, state, and federal arguments, with the international human rights perspective on these same practices. This is the argument structure that the appellate defenders used the House case and that Attorney Plano used in the Belanger case. ${ }^{115}$

\footnotetext{
113 See supra Part II, section (a).

114 See supra Part II, section (c).

${ }^{115}$ See supra Part II, sections (b)-(c).
} 
In addition to these takeaways, there are also a few cautionary notes that should be emphasized when considering the use of a human rights argument in domestic court. First, think carefully about who the judge or decision-maker is when deciding when to bring a human rights argument. If the judge is known to be friendly to these arguments, go for it. However, if the judge does not recognize federal authority, for example, it would not be a good idea to try out a human rights argument for the first time in his courtroom.

Be careful of overuse or too much reliance on human rights arguments when the facts of a case or the law are not strong. Human rights arguments, especially when offered for the first time before a particular decision-maker, should never be thrown out as a last ditch or Hail Mary attempt at persuasion. If used in this way, human rights arguments could easily be written off in the future.

Lastly, the human rights arguments presented in this article were merely persuasive and not presented as binding on the decision maker. There are very few instances when human rights law can be enforced in a U.S. court, ${ }^{116}$ and in those narrow cases, bringing on a human rights expert or co-counsel, at the very least, should be considered.

\section{CONCLUSION}

International human rights offer legal aid attorneys and public defenders in the U.S. an additional tool for litigation in U.S. courts on behalf of clients living in poverty. Persuasive human rights arguments are being used effectively before local, state, and federal courts across the U.S., and should be considered for inclusion in briefs and oral arguments as demonstrated by the cases discussed in this article.

\footnotetext{
${ }^{116}$ There a few international human rights treaties, including the Hague Convention on the Civil Aspects of International Child Abduction, which have been codified as U.S. law, and can be binding on private parties. See 42 U.S.C. §§ 11601-11611; HANDBOOK, supra note 4, at 38 (discussing enforcement of the Hague Convention in U.S. courts).
} 
